ECLAC

ECONOMIC COMMSSION FOR LATIN AMERICA AND THE CARIBBEAN

Office in Brazil

\title{
Integration in Latin America - Trends and Challenges
}

Renato Baumann

The views expressed in this work are those of the author and do not necessarily correspond to the official position of the institutions involved. 


\title{
Integration in Latin America - Trends and Challenges
}

\author{
Renato Baumann *
}

\section{Introduction}

Regional trade agreements have had a significant presence in the design of international and productive policies in Latin American and Caribbean countries since the early 1950s. Fifty years later, the region has not reached the degree of economic interrelation found, for instance, in Western Europe, but the concern with promoting regional integration has been a tradition in an impressive amount of speeches and declarations by policy makers in the last decades.

The emphasis in regional agreements as a policy tool has changed quite significantly over time, with a recent boom from the mid-1980s to mid-1990s, but at present this has been challenged by a number of features of the international scenario.

The weakening of multilateral negotiations and the multiplicity of bilateral agreements with countries in other regions might affect regional trade both via trade diversion and through investment decisions, considering a larger time horizon. International capital movement might affect exchange rates and output growth, hence influencing trade. At the same time the need for new, broader negotiating agenda, from simply dealing with trade issues to taking into consideration topics not directly related to trade but rather to competition, labour standards, environmental issues and others increase the difficulties in designing integration strategies. Even more so if the group of countries that aim at integrating their economies present markedly different characteristics.

There are at present more challenges than ever to the integration processes in the region. The point made here is that regional integration is not something automatically desirable or a sufficient condition to promote economic and social development. The very lack of clarity in identifying for what purpose a country should enter (or remain in) an integration process not only may impair the negotiating process but also influences the degree of success that might be obtained from this mechanism.

This article - an extension of a presentation made at the German Development Institute Conference on Regional Economic Integration Beyond Europe held in Bonn in December, 2007 - discusses these and other aspects related to regional integration in Latin America and the Caribbean. Following this introduction the second section describes in generic terms the main integration exercises found today in Latin America and the Caribbean. Section 3 shows the existence of a multiplicity of agreements with some overlapping and discusses some of the negative implications that might follow from this web of different preferential treatments with different partners. The fourth section brings about the discussion about the rationale for regional integration. It shows that over time the Latin American arguments for promoting regional integration have changed quite

\footnotetext{
* UN/ECLAC and University of Brasilia. The views expressed here are my own, and do not necessarily correspond to the official position of these two institutions.
} 
substantially. It also shows that at present there is a certain lack of sound arguments to motivate efforts in that direction. The fifth section presents some recent steps taken in the region towards monetary cooperation, and the last section presents a few concluding remarks.

\section{Integration Schemes in the Americas}

Preferential trade agreements have gained momentum in the region in recent years Until 1991 trade preference agreements accounted for some $8 \%$ of total regional exports. By 2005 there were 68 agreements, 51 of which were intra-regional preferences and 17 with countries in other regions, affecting about two-thirds of the region's total exports (ECLAC 2006).

The sub regional initiatives that comprise integration schemes in the Americas are varied. Some have ambitious purposes, such as the creation of common markets, whereas others are essentially free trade agreements. They can be presented in a geographical sequencing. Moving from the Southern Cone towards the Artic Sea we find the following initiatives.

\section{A) LAIA - Latin American Integration Association}

The Latin American Integration Association (LAIA) was created in August 1980. It replaced the former LAFTA (Latin American Free Trade Association), created in 1960. It is formed by Argentina, Bolivia, Brazil, Chile, Colombia, Cuba, Ecuador, Mexico, Paraguay, Peru, Uruguay and Venezuela. Its objectives are to create a Latin American common market in the long run and in a gradual manner, by means of tariff preferences, as well as the signing of regional agreements.

There are at present 10 preferential trade agreements in South America within LAIA comprising 45 bilateral relations and 90 tariff chronograms (Veiga and Rios 2007). In 2006 LAIA created the Free Trade Space, aiming at facilitating market access, the adoption of common norms and disciplines, and providing support to less developed member-countries.

\section{B) MERCOSUR}

The Mercado Común del Sur (MERCOSUR) was formed by Argentina, Brazil, Paraguay and Uruguay by the Treaty of Asunción, signed in March 1991. Associate members are Bolivia, Chile, Colombia, Ecuador and Peru. Venezuela signed a membership agreement in June 2006, but before becoming a full member its entry has to be ratified by the national parliaments of the four original members.

Its objectives are to create a common market with free movement of goods, services and productive factors; adopt a common external policy; coordinate common positions in international forums; and coordinate sector and macroeconomic policies.

Its Common External Tariff (CET) covers some $85 \%$ of intra-regional trade. Great exceptions remain the sugar and automobile sectors. The CET is effective and equal to national tariffs for $35 \%$ of total trade by MERCOSUR countries. From those, products stemming for 20 percentage points have zero tariffs. That is, only $15 \%$ of MERCOSUR adopt CET (Veiga and Rios 2007). A number of non-tariff barriers remain in regional trade. 
As from December 2008 Brazil has announced its decision to eliminate the double charging of trade tariffs, in order to reduce costs (even at a loss of tariff revenue for some members, such as Paraguay, which depends on this item for almost $20 \%$ of its fiscal revenue). Brazil has also announced its intention to reduce the nationalized component of imports from Paraguay and Uruguay, a political decision still to be translated into technical procedures.

MERCOSUR has opted for remaining an inter-governmental exercise, instead of creating a supranational structure, as in the European Union and in other integration exercises in the region. This has, of course, costs and benefits. Among the former, the low degree of implementation of the common rules in MERCOSUR is often related to the lack of supranational entities that might impose higher degree of discipline. The benefits of the inter-governmental model, on the other hand, stem from its relative flexibility: in several critical situations this lack of institutional rigidity has allowed for changes in the negotiating process.

MERCOSUR has signed some 17 agreements, most of them in the period 2004-06. Not all of these agreements comprise trade preferences. Some are only 'base-agreements' with generic objectives and common purposes. But the total number of agreements mirrors the 'global trader' perspective adopted by MERCOSUR since its early days.

\section{C) Andean Community of Nations (ANCOM)}

The Andean Community of Nations (ANCOM) was formed in May 1969 by Bolivia, Colombia, Ecuador and Peru. Until 1996, it was known as the Andean Pact. Originally both Chile and Venezuela were member countries. The former left the Community in 1974 opting for a more open multilateral approach and the latter in 2006 based on the argument that the negotiations of Colombia and Peru with the United States would affect the essence of the Community. Associate members are Argentina, Brazil, Chile, Paraguay and Uruguay. Observer members are Mexico and Panama.

ANCOM's objectives are to promote the harmonic development of the membercountries in equal conditions, through integration and economic and social cooperation; to gradually form a Latin American common market; to foster sub-regional solidarity; and to reduce external vulnerability.

The Andean Community differs from MERCOSUR in that there are no exceptions among the products affected by preferences, it has common norms with regard to trade mechanisms such as anti-dumping and safeguards policies, and it adopts common norms also for trade in services, investment, intellectual property and competition. It has also a rather complex institutional structure.

In 2006 Chile has accepted the invitation to (re)join the Andean Community as an associate member. The purpose is to form a free trade zone on the Latin American Pacific coast.

The Andean Community has negotiated trade agreements with the European Union and - in the case of Colombia and Peru - with the US, but this remains to be approved by the US Congress.

Negotiations between MERCOSUR and the Andean Community were completed in 2004; they are essentially bilateral trade concessions. 
D) Bolivarian Alternative to Latin America and the Caribbean (known by its Spanish acronym ALBA) / People's Trade Agreement

The Bolivarian Alternative is an initiative led by Venezuela and Cuba as an alternative to the negotiations for a Free Trade Area of the Americas (FTAA). In December 2004 these two countries signed a bilateral agreement. In April 2006 Bolivia joined in the People's Trade Agreement, and in January 2007 Nicaragua joined in. Observer members are: Antigua \& Barbuda, Dominica, Ecuador, Haiti, Honduras, St Kitt \& Nevis, St Vincent \& Grenadines and Uruguay.

The People's Trade Agreement comprises trade facilities and complementarities in the energy sector. In January 2008 the ALBA Bank was created, adding a new dimension to the initiative. ${ }^{1}$

\section{E) The South-American Union of Nations (UNASUR)}

MERCOSUR and the Andean Community signed in 2004 a free trade agreement which, together with Chile, Guyana and Suriname shall lead to the formation of a SouthAmerican Union of Nations. It was originally (until 2007) called South-American Community of Nations (CASA in its acronym in both Spanish and Portuguese). Its members are Argentina, Bolivia, Brazil, Chile, Colombia, Ecuador, Guyana, Suriname, Paraguay, Peru, Uruguay and Venezuela. Headquarters are to be located in Quito, Ecuador and the Unasur Treaty is to be initiated by June, 2008.

The goal is to gradually form a free trade area in South America, as well as to provide economic complementarities among countries in the region. UNASUR represents a new model of regionalism, not focused predominantly on trade issues. Its agenda comprises other issues, such as energy integration and infrastructure, as well as social and cultural themes. Together with LAIA, these are the two integration schemes that comprise all South American countries.

\section{F) The G-3}

The G-3 group was formed in June 1994 and entered operation in January 1995. Its original members were Colombia, Mexico and Venezuela.

Its objectives were to eliminate trade barriers for goods and services, to promote fair competition, foster investment opportunities, protect intellectual property and foster cooperation among members. The relative importance of the group has never been too remarkable: by 2003 intra-regional exports in relation to total exports corresponded to some $28 \%$ in Colombia (basically its bilateral trade with Venezuela), $3 \%$ for Mexico and $13 \%$ for Venezuela. Venezuela decided to abandon the group on the second semester of 2006, at the same time of its withdrawal from ANCOM, so the group was dismantled.

\section{G) Central American Common Market (CACM)}

\footnotetext{
${ }^{1}$ Details on ALBA Bank will be discussed in Section 5.
} 
The Central American Common Market (CACM) was formed in December 1960 by El Salvador, Guatemala, Honduras and Nicaragua. Costa Rica joined the group in 1963. Its objective is to create a common market among member countries.

CACM became a free trade zone in 2001, although with the exception of some agricultural products. Efforts are being made for a common policy on investment and trade in services, trade concessions, norms for government procurement, investment, property rights, labour and environmental issues, among others.

The Common External Tariff covers $95 \%$ of the tariff lines, with an average rate of 6\%. As similar to the Andean Community, CACM has a rather diversified institutional structure. Another difference with regard to MERCOSUR is that the members of CACM can negotiate trade agreements on an individual basis with countries from other regions.

CACM has had an intense negotiating activity in 2002-06. The CAFTA-RD (agreement with the US) was signed by all countries but Costa Rica in 2006, and submitted to a popular referendum (being approved) in this latter country in 2007. Given the importance of trade with the US (and the risk of trade diversion) one major issue raised by these agreements is to what extent the relations on a new basis with the US will affect regional integration efforts.

\section{H) Association of Caribbean States (ACS)}

The Association of Caribbean States (ACS) was formed in July 2004 by Antigua \& Barbuda, Bahamas, Belize, Colombia, Costa Rica, Cuba, Dominica, Dominican Republic, El Salvador, Granada, Guatemala, Guyana, Haiti, Honduras, Jamaica, Mexico, Nicaragua, Panama, St Lucia, St Kitts \& Nevis, St Vincent \& Grenadines, Suriname, Trinidad \& Tobago and Venezuela. Associate members are: Aruba, France, Netherlands Antilles and Turks \& Caicos Islands.

It aims at promoting consultation, cooperation and concerted action with regard to cultural, economic, scientific and technological development, as well as trade liberalization and investment regulation among all the countries of the Caribbean. Focus is concentrated in four major areas: trade, transport, tourism and natural disasters.

Its potential is often seen with scepticism since: i) there are marked differences among member countries not only in trade policies, but also in political and cultural terms; ii) it lacks clear definition as to its long-term objectives, its mechanisms to coordinate policies and its potential relations with third countries; iii) Cuba's membership raises questions as to how effective can be its future negotiations with the US.

\section{I) Caribbean Community (CARICOM)}

The Caribbean Community (CARICOM) was formed in July 1973 by Antigua \& Barbuda, Bahamas, Barbados, Belize, Dominica, Granada, Guyana, Haiti, Jamaica, Montserrat, St Lucia, St Kitts \& Nevis, St Vincent \& Grenadines, Suriname and Trinidad \& Tobago. Associate members are: Anguila, Bermuda, British Virgin Islands, Cayman Islands and Turks\&Caicos Islands

CARICOM's objective is to promote economic integration of member-countries by means of a common market, coordination of a common external policy and functional cooperation in terms of health, education, culture, communication and industrial relations. 
In 2002 a common legislation was adopted for commercial defence mechanisms and technical and sanitary rules, as well as norms regulating trade in services, intellectual property and competition policy.

CARICOM has perhaps the most complex institutional structure of all American integration experiments. Intra-regional trade has been dynamic in recent years, surpassing $20 \%$ of total exports.

Relations among the English-speaking Caribbean countries - with the recent adhesion of Dutch-speaking Suriname and French-speaking Haiti - have always gone well beyond trade relations. Most member countries are former European colonies and until recently their products had benefited from differentiate treatment in the European market on the basis of specific trade agreements.

In 2006 a CARICOM Single Market (CSM) has been created to provide free movement of goods and services, as well as of labour and capital. All 12 countries participate in the initiative, which comprise harmonization in economic policies, leading to a common currency as of 2009. Between 2010 and 2015 a full monetary union is to be implemented, with policy coordination in several sectors. Central issues for Caribbean countries are energy and labour movement. Countries systematically demand special and differentiated treatment in the WTO and manifest increasing concern with the progressive elimination of preferences under the Cotonou Agreement.

\section{J) North-America Free Trade Area (NAFTA)}

The North-America Free Trade Area (NAFTA) was created in December 1992 by Canada, Mexico and the United States of America and has been in operation since January 1994. Its objective is to create a free trade area among the three North-American countries.

Most import tariffs and other restrictions to trade among the US, Canada and Mexico were eliminated over the first ten years of implementation. The average Mexican fell from about 12 percent in 1993 to 1.3 percent by 2001, whereas US tariffs on Mexican products fell from 2 percent to 0.2 percent $^{2}$.

Many distortions remain, nevertheless. Some tariff quotas for sensitive agricultural products are to be eliminated only in 2008 , and all member countries have continued to use anti-dumping and countervailing duties according to their own national trade laws.

Since NAFTA provisions go beyond trade issues and affect investment flows, trade in services, government procurement, environmental policies protection to intellectual property rights and other dimensions this has imposed a number of shocks on the Mexican economy and forced it to close adherence to the business cycle of the US economy.

Some studies (such as Baumann and Franco 2002) have also found indication that NAFTA has led to trade diversion, negatively affecting exports from other Latin American countries into the US market

NAFTA differs from the other initiatives listed above in that it aims exclusively at creating a free trade area, with no further objectives related to development, even though the negotiated agenda goes beyond purely trade issues.

\footnotetext{
${ }^{2}$ Tariffs in the bilateral trade between the US and Canada have been low since their signing of the US-Canada FTA in 1989.
} 
Despite all these regional integration agreements, intra-regional trade in Latin America is still relatively low when compared to European standards (Table 1) ), and show varied trajectories and different intensities among different integration exercises. The most pronounced increase in the share of regional exports was experienced by MERCOSUR until the late 1990s whereas the most significant fall in that share is also found in MERCOSUR thereafter.

Table 1: The relative (\%) importance of regional exports on total exports

\begin{tabular}{|l|r|r|r|r|r|r|}
\hline & \multicolumn{1}{|c|}{$\underline{190}$} & \multicolumn{1}{c|}{$\underline{\underline{195}}$} & $\underline{1998}$ & $\underline{\underline{2000}}$ & $\underline{\underline{2002}}$ & $\underline{2006}$ \\
\hline LAIA & 12.1 & 17.4 & 17.2 & 13.1 & 11.3 & 14.6 \\
\hline Andean Community & 4.1 & 12.3 & 14.2 & 8.5 & 10.0 & 10.2 \\
\hline MERCOSUR & 8.9 & 20.2 & 25.3 & 20.7 & 11.4 & 13.5 \\
\hline CACM & 13.9 & 16.6 & 18.4 & 15.7 & 16.9 & 17.8 \\
\hline Total Latin America \& the Caribbean & 13.9 & 19.8 & 20.2 & 17.4 & 15.4 & 17.4 \\
\hline European Union & 64.9 & 64.0 & 63.2 & 62.4 & 61.8 & $67.3^{*}$ \\
\hline
\end{tabular}

Sources: ECLAC $(2006,2007)$ and www.wto.org.

(*) EU25

\section{Diverging Trends in Regional Integration}

Due to several factors - among them the disenchantment with multilateral negotiations after the failure of the Seattle meeting, in preparation for the Doha Round of the WTO - there has been in many regions an increasing number of bilateral and plurilateral agreements. They establish trade preferences but often comprise also disciplines regulating issues that frequently are not directly related to trade issues. Property rights, government procurement policies, competition policies, environmental issues, labour policies and others are often part of the commitments required for the signing of these agreements.

More often than not they involve a developed country and one or more developing economy. In these cases the differential in negotiating power has often led to an enlargement of the agenda, involving themes that have not been accorded in WTO negotiations. Agreements among sets of developing countries tend to be more focused in trade concessions and eventually in complementary policies related to economic and social development.

Latin American and Caribbean countries are no exception and in fact have been quite active in participating in this new wave of agreements. An increasing number of countries have negotiated agreements with countries in other regions as well as with neighbouring partners. The parallelism between these several integration initiatives and a number of extra-regional agreements might affect the outcome of regional integration schemes. Table 2 illustrates the current situation. 


\section{Table 2: Variable Geometry in Latin America and the Caribbean (January 2008)}

\begin{tabular}{|c|c|c|}
\hline & Signed Agreements & Present Negotiations \\
\hline Intra-Regional & $\begin{array}{l}\text { LAIA, MERCOSUR, ANCOM, } \\
\text { CACM, CARICOM, NAFTA, ALBA, } \\
\text { UNASUR, SACN, ACS } \\
\text { MERCOSUR-Chile; MERCOSUR- } \\
\text { Bolivia } \\
\text { MERCOSUR-Peru; MERCOSUR- } \\
\text { Colombia, Ecuador, Venezuela } \\
\text { Venezuela-CARICOM; Chile-Bolivia; } \\
\text { Colombia-CARICOM; Chile- } \\
\text { Colombia; Bolivia-Mexico; Chile- } \\
\text { Ecuador; Colombia-Venezuela; } \\
\text { Chile-Peru; } \\
\text { Costa Rica-Mexico; CACM- } \\
\text { Dom.Rep;; CACM-Chile; Costa Rica- } \\
\text { Trinidad\&Tobago; Costa Rica- } \\
\text { CARICOM; Nicaragua-Mexico; } \\
\text { Mexico-Guatemala, EI Salvador, } \\
\text { Honduras } \\
\text { CARICOM-Dom.Rep. } \\
\text { Chile-Bolivia; Chile-Venezuela; } \\
\text { Chile-Colombia; Chile-Mexico; Chile- } \\
\text { C.America; Chile-Cuba } \\
\text { Mexico-Venezuela, Colombia; } \\
\text { Mexico-Costa Rica; Mexico-Uruguay; } \\
\text { Mexico-Panama }\end{array}$ & $\begin{array}{l}\text { CARICOM - MERCOSUR } \\
\text { CAN - Guatemala, EI Salvador, } \\
\text { Honduras } \\
\text { Mexico - MERCOSUR }\end{array}$ \\
\hline Extra-Regional & $\begin{array}{l}\text { Chile - Canada, USA, EU, EFTA } \\
\text { Mexico - USA, Canada, EFTA, UE, } \\
\text { Japan } \\
\text { CAFTA-Dom.Rep-CACM } \\
\text { Dom.Rep.-USA; Ecuador - USA } \\
\text { Costa Rica - Canada } \\
\text { Chile-S.Korea; } \\
\text { Chile-New Zealand, Singapore, } \\
\text { Brunei } \\
\text { MERCOSUR - India; MERCOSUR- } \\
\text { Israel; } \\
\text { MERCOSUR-SACU } \\
\text { Peru - Canada; } \\
\text { Peru - USA; Colombia - USA } \\
\end{array}$ & $\begin{array}{l}\text { Ecuador - USA } \\
\text { MERCOSUR - European Union } \\
\text { CACM - European Union } \\
\text { CARICOM - European Union } \\
\text { CARICOM - Canada } \\
\text { Chile-China; Peru - Thailand } \\
\text { MERCOSUR - Persian Gulf } \\
\text { Countries } \\
\text { Brazil-Morocco; Brazil - Egypt }\end{array}$ \\
\hline
\end{tabular}

Source: adapted from ECLAC (2006, p. 84). 
Apart from the potential risks in terms of trade diversion implicit in this web of agreements, this increasing simultaneity of agreements brings about costs of several kinds. They imply higher administrative costs, as custom officials have to deal with different tariff rates for any given product, according to their geographic origin. Simultaneous agreements raise the risk of having to adopt more ambitious norms than those already agreed at the WTO level, and even more so if the negotiations take place between countries of markedly different economic sizes: developing countries are more vulnerable to interest groups in industrialised groups. The mushrooming of preferential agreements might also negatively affect the very existence and operational capacity of the WTO, by weakening its role as a ruler of international trade. ${ }^{3}$

UNCTAD (2007) has alerted to the fact that a web of preferential trade agreements is not a sufficient condition to foster trade. The point can be illustrated by the African experience. It is well known that the African continent does not show particularly brilliant results when it comes to the relative importance of regional trade: trade within the Maghreb Union, the Economic and Monetary Community of Central Africa and the Common Market for Eastern and Southern Africa does not exceed 5 per cent. In other initiatives, such as the Economic and Monetary Community of Central Africa this figure is less than 2 per cent, even though in others, like the West African Economic and Monetary Union regional trade reached 26 per cent in 2006 .

According to UNCTAD the small weight of intra-regional trade in Africa, despite the existence of several and often overlapping regional trade agreements, is explained by the small countries being specialized in primary commodities, whereas the light manufactures some of them export are basically destined to third markets. Yet the number of simultaneous agreements is remarkable: UNCTAD (2007) indicates no less than 13 regional integration initiatives in Africa[, involving various sets of countries.

The picturing of the present situation in Latin America may be not as complex as in Africa, with regard to the number of agreements. But here, too, there is an increasing web of preferences, as shown in Figure 1.

Latin American integration exercises present on average higher percentages of regional trade, and the differences among them in this regard are smaller than in the African continent. Yet the lesson that comes out from this picturing is that trade agreements per se do not necessarily lead to increased trade among parties. Other factors, such as the implementation of agreements as well as the supply and demand structures of the participating economies have to be taken into account. Some basic conditions have to be met so as to be possible to exploit the potential effects of such agreements on regional trade as well as on the structures of production and demand.

\footnotetext{
${ }^{3}$ See the analysis of Schott (2008) in this volume.
} 


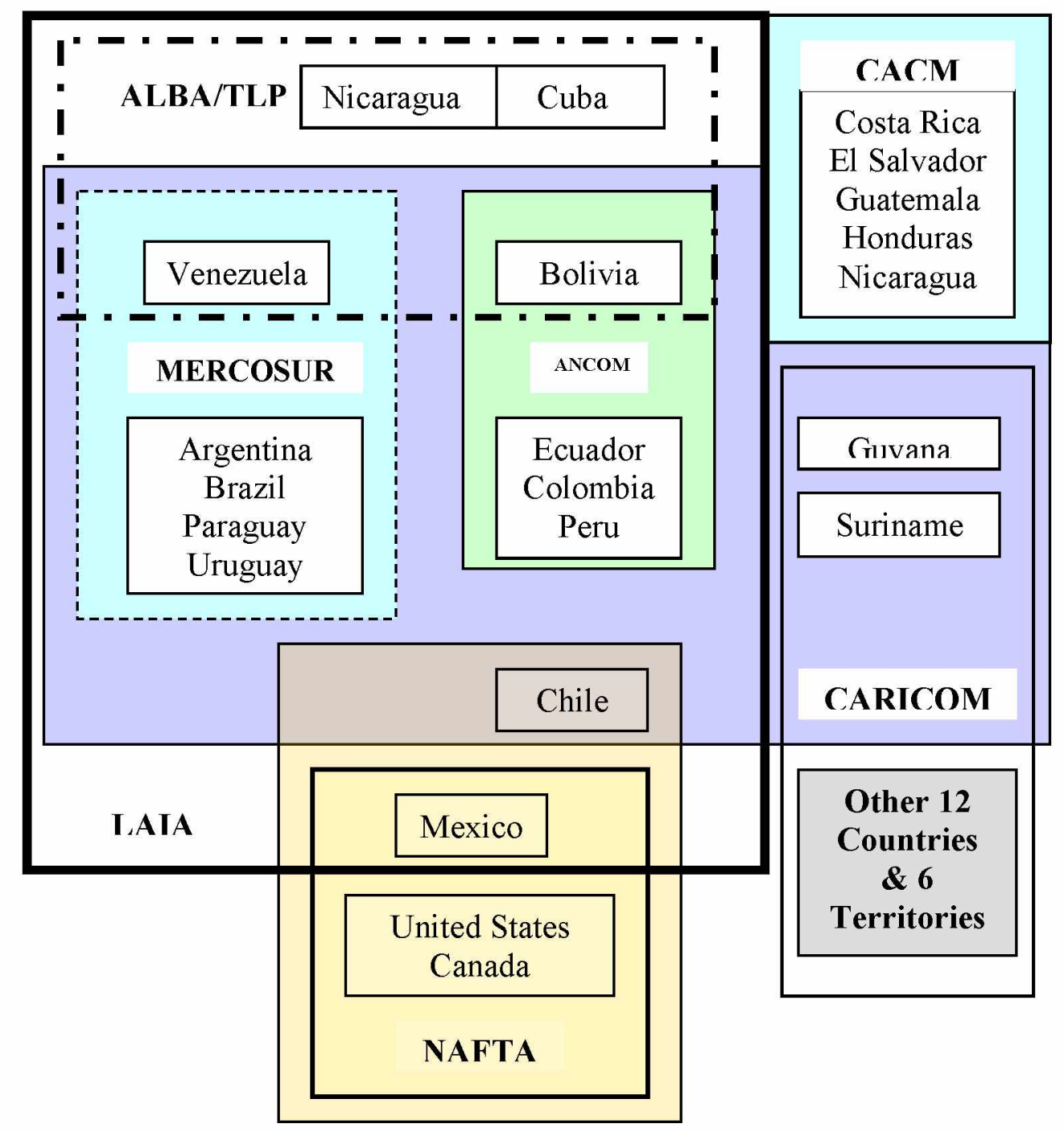

Source: Adapted from Vaillant (2007, p. 15).

Even if the different agreements were conceived as 'building blocks', leading to a higher degree of free trade, the matter for concern would still go beyond the existence of an increasingly complex web of trade agreements. According to joint work by technical staff at LAIA, MERCOSUR Secretariat and the Andean Community (Comunidad Andina de Naciones 2006) there is a very slow convergence towards free trade in the region, taking into account the chronograms of tariff reduction established in the various agreements: in 2006 between $35 \%$ and $60 \%$ of regional exports (varying in accordance to the estimation method - whether by tariff lines or import value) were free of tariffs, whereas by 2018 those percentage is scheduled to reach only between $65 \%$ and $95 \%$. 
ECLAC (2006) has advocated the importance of promoting a faster convergence among these preferential schemes, as well as adopting common norms so as to avoid the adoption of non-trade barriers in regional trade.

Apart from the basic argument of reducing trade distortions by means of freeing trade flows, there are (at least) two other reasons that support the emphasis given to the need for promoting faster convergence of these schemes. First is the fact that tariff preferences now correspond to an increasing share of trade in Latin American and Caribbean countries. Taken as a percentage of total exports from these countries we have the situation as presented in Table 3.

Table 3: Trade Preferences in Latin America and the Caribbean ( $\%$ of Total Trade)

\begin{tabular}{|c|r|r|r|}
\hline $\begin{array}{c}\text { Selected } \\
\text { Years }\end{array}$ & \multicolumn{1}{|c|}{$\begin{array}{c}\text { Intra-regional } \\
\text { Preferences }\end{array}$} & \multicolumn{1}{c|}{$\begin{array}{c}\text { Extra-regional } \\
\text { Preferences }\end{array}$} & \multicolumn{1}{c|}{ No Preferences } \\
\hline 1991 & 8.4 & -- & 91.6 \\
\hline 1995 & 11.2 & 31.6 & 57.2 \\
\hline 2000 & 11.7 & 45.6 & 42.7 \\
\hline 2005 & 12.5 & 51.5 & 37.0 \\
\hline
\end{tabular}

Source: ECLAC $(2006,2007)$.

Over two-thirds [of total trade by Latin American and Caribbean countries are done on the basis of some type of intra- or extra-regional preferential market access. Reducing the disparities likely to be found in the overlapping preference schedules might contribute to stimulating regional trade.

Further, regional integration schemes favour the exports of products with higher value-added. For instance, in 2004 the composition of the export bills of the various integration schemes were as shown in Table 4.

Table 4: Product Groups in Intra-Regional and Extra-Regional Trade

\begin{tabular}{|l|r|r|r|r|}
\hline & \multicolumn{2}{|c|}{ Intra Regional } & \multicolumn{2}{c|}{ Extra Regional } \\
\hline & Raw Material & Manufactures & Raw Material & Manufactures \\
\hline Andean Community & 14.3 & 85.7 & 64.3 & 35.7 \\
\hline MERCOSUR & 16.2 & 83.8 & 32.3 & 67.7 \\
\hline CACM & 15.8 & 84.2 & 21.7 & 78.3 \\
\hline CARICOM & 21.6 & 78.4 & 44.4 & 55.6 \\
\hline
\end{tabular}

Source: ECLAC (2006).

To the extent that policy-makers consider it desirable to increase the degree of industrialisation of the products exported by Latin American and Caribbean countries it is worth developing the regional market, still the main market for manufactured products. Reduced disparities in preferences would in principle enlarge such market. The argument is, however, not free from criticism: intra-regional trade being more intensive in products with higher value added makes it more sensible to the business cycle, adding to the price volatility of commodities exported to third countries.

This perception of regional agreements having different impact on various sectors, coupled to the challenge of pursuing intra- and extra-regional negotiations at the same time, leads to a discussion of what are the arguments for promoting regional integration. Latin 
America has a long tradition of advocating for integration. But the arguments supporting this view have changed over time, as shown in the next section.

\section{The Changing Rationale for Regional Integration in the Americas}

The debate on the types of regional agreements has been revived recently in the context of the discussion about the ideal agenda for the negotiations of a Free Trade Area for the Americas (FTAA). As Devlin and Giordano (2004) have put it, the questions involved an option between what they have called the 'old' and the 'new' regionalism, the former being essentially concerned with an import substitution approach, with the negotiating agenda centred on trade issues and concessions to be granted in a gradual pace. The 'new' regionalism would, in contrast, be far more ambitious, with a much broader negotiating agenda, comprising dispute settlement mechanisms, competition policies, and government procurement criteria, among others.

The option between an 'old' and a 'new' approach would determine the pace and the type of negotiation that might have taken place had the FTAA project not been killed by precisely a mismatching of perceptions in this regard.

Part of the difficulties in dealing with this issue stem from the lack of clarity of what role might be expected today from regional trade agreements, given that a number of circumstances in the international scenario affect - in an unprecedented manner - the potential outcome of regional integration exercises.

The idea of creating a common market to facilitate industrialization in the region by means of enlarging the domestic markets and therefore allowing for gains from productive plants of larger scale - has been present in the reasoning about regional integration by some think tanks such as ECLAC since the late 1940s.

The first steps to realize this idea were taken in Central America, where already in 1951 the basis for what later became the CACM was established. In the 1950s and 1960s the perspective of recurrent balance of payments disequilibria, reducing the access to imported capital goods, required for making viable the priority given to industrialization, reinforced the demand for regional integration (Baumann 2000). The approach was that trade preferences should be granted gradually, so as not to disturb the (limited) access to capital goods. Moreover, those preferences should be granted to the highest possible number of countries in the region, with differential treatment given to smaller economies (ECLAC 1952, 1959). This reasoning became the basis for the creation - in 1960 - of LAFTA.

The 1970s were a period of very low interest in regional integration in Latin America. Difficulties comprised the payment constraints following the first oil shock, limitations imposed by the decision process in LAFTA and - no less important - the fact that several countries in the region had military governments, not quite prone to make concessions that affect national sovereignty.

The second oil crisis plus the debt crisis imposed a shortage of foreign currencies to most Latin American countries. Reduced trade performance, coupled to idle capacity in some countries and excess demand in others led to regional integration gaining momentum in the political agenda of the region since the mid-1980s (CEPAL 1994).

In this new era regional integration was seen as not only a means to widen domestic markets and allowing for scale gains, but it also proved a way out of crises: regional trade 
makes it possible in the short run to use installed capacity, and clearing schedules adopted by central banks in the region allowed for regional trade with less need of scarce foreign currencies. Furthermore, in the long run what makes integration sustainable is not the unlimited elimination of trade barriers, but rather the efforts to complement productive structures, so integration exercises should be seen as also a tool for the creation of common economic spaces. Lastly, because the renewed interest in regional integration took place at the same time that most economies adopted more liberal trade policies as a means to fight inflation, not only the integration processes should be designed in such a way to be compatible with multilateral opening (the so-called 'open regionalism', with regional agreements being 'building blocks' to multilateralism), but exports to neighboring countries should be seen as a 'learning process', by which producers could gain experience that would later make them able to try and explore more sophisticated markets (ECLAC 1984; CEPAL 1985).

The 1990s - the 'decade of the reforms' in Latin America - added new arguments to those already listed. The economic reasoning in the 90 s stressed competitiveness. There are additional benefits stemming from regional integration in that it allows for the reduction of unproductive rents related to lack of competitiveness, affects expectations of domestic and foreign investors, reduces transaction costs, increases productive efficiency, therefore contributing to price stability and facilitating the absorption of technical progress by stimulating less vertical productive processes, sub-contracting of smaller firms and the employment of qualified workers. The liberalization of regional trade should also provide support to intra-industry specialization, given that the products traded within the region tend to be more technology-intensive than the exports to the rest of the world. According to the new thinking, the benefits of integration go even further, by affecting positively the economic and institutional environment: joint infrastructure projects, as well as joint initiatives in areas such as education and development of capital markets have widespread effects (ECLAC 1994).

There were, hence, in the 1950s, 1960s, 1980s and 1990s clearly identifiable arguments in favour of policies stimulating regional integration. In the years $2000 \mathrm{~s}$, however, new overall conditions impose a challenge in trying to identify clear arguments for integration.

First, the outcome of trade concessions is affected by the international movement of capital; hence trade liberalization can not be thought of independently of the policies towards the capital account. This is particularly relevant in a context such as the Latin American, where there has been little if any macroeconomic coordination.

Second, regional negotiations (the regional agenda) should go beyond the trade dimension: there is an increasing need to deal, for instance, with development financing and infrastructure themes, such as energy, environmental policies and water supply, not to speak of measures to improve financial cooperation. ${ }^{4}$ What is not clear, however, is which non-trade topics should be included in the negotiations. The perception of what is relevant and what is a sensible issue in this regard varies significantly among different economies. This can be a major constraint in particular when a given regional agreement is formed by countries with very different economic conditions.

\footnotetext{
${ }^{4}$ See the contribution by Pommerleano (2008) in this volume.
} 
Third, international negotiations are in every country an attribute of the executive power, the one with the means, structure and empowerment to carry out such negotiations. Reaching agreement between two countries is easier on areas related to the executive power than reaching convergence on subjects that concern the legislative and the judiciary. In part as a result of this difficulty having been perceived by several agents in recent years there has been an increasing demand by representatives of the legislative and judiciary powers to participate (ex-ante) in the negotiation process, having more active voice in the design of the negotiating strategies.

A broader negotiating agenda involving various agents demands far more intense efforts to reach previous consensus at a national level than a focused agenda. And even bigger efforts are needed to reach convergence among different countries.

$\mathrm{Be}$ it as it may, the record of regional integration in Latin America in the years 2000s show relatively slow progress. There are mainly weak (or inexistent) institutions, specially with regard to efficient dispute settlements mechanisms, an overall absence of macroeconomic coordination, limited treatment of asymmetries and of non-trade disciplines, all of which provides relatively low credibility to the integration purposes.

This is due in part to the fact that regional integration takes place in parallel to an increasing number of extra-regional preferential agreements. It is also due to the fact that given the ambitious negotiating agenda in several exercises, comprising themes that do not traditionally belong to integration processes, such as consumer rights, government procurement, competition policies and others - the domestic political environment in several countries is not compatible with the concessions required to foster integration processes.

Given these obstacles, what are the external conditions that might influence the outcome of integration exercises in the present decade? To start with, the high mobility of international capital, in a context where most countries have opened both their trade and capital accounts, is a major element affecting bilateral exchange rates, therefore determining trade flows and output growth, and hence also the expectations of potential investors.

Second, infrastructure themes (energy, transportation and communication in particular) have to be considered, should Latin American policy-makers intend to sustain output growth rates and foster economic and social development. That brings about the related theme of long-term financing. These are issues that go well beyond the traditional agenda based on trade concessions. Some initiatives have been launched to deal with financing, to be considered in the next section. The aspect that concerns us here is that regional agreements are each time more pressed to deal with these themes, and convergence of ideas about how to deal with them is often scarce.

Third, the weakening of the WTO, in parallel to the mushrooming of bilateral and plurilateral agreements impose a challenge to regional preferences in that they increase the probability of trade diversion, negatively affecting regional trade. As a consequence, it reduces the margin for exploiting the potential these regional agreements might provide as a tool to foster economic development via changes in the productive structure.

Fourth, the emergence of new actors in the international scenario (like some Asian countries), in parallel to the weakening of some industrialized economies, raises the perspective of a new 'policentrism' in international economic and political relations. This increases the list of 'natural candidates' that Latin American countries should look for in their selection of potential partners for bilateral agreements. To the extent that recent 
agreements involve themes that go beyond purely trade subjects, the approximation with different partners at the same time might have damaging effects on a given group of countries participating in the same regional initiative. For instance, in South America MERCOSUR has opted for a South-South approach, signing agreements with developing economies in other regions, whereas most other countries have put efforts in improving access to the US market. As mentioned earlier, in the Andean Community the agreements negotiated by Colombia and Peru with the US have motivated the exit of Venezuela from that group.

Fifth, agreements negotiated by each country individually with third parties might deal with one same subject in different ways, leading to different rules than those prevailing within the regional agreements.

It is, therefore, less clear in the present decade, as compared to previous periods, what each group of countries can expect from regional preferential agreements. It is not an easy task within each country individually to identify the national motivation to adhere to a given integration exercise. It is even more difficult to reach consensus among economies with different perspectives with regard to their participation in the international scenario. This is one of the major shortcomings in designing the trajectories for integration exercises and hence one of the major obstacles to exploiting the potential changes in the economic structure that theory would allow us to expect from regional integration ${ }^{5}$.

Depending on how they are designed regional agreements can be considered as a escape valve to a failing multilateral system. But they can also be 'building' or 'stumbling' blocks to the multilateral system. Betting on trade agreements as a means to live in a world with missing multilateral trade rules might be a risky option, as overall disciplines might be replaced by bilateral pressure. Perspectives of a failure of the Doha Round have already led to a booming of preferential trade agreements. The remaining question is, however, to what extent these agreements are sufficient conditions to foster trade. Take, for instance, Mexican exports to the US. Mexican products benefit from NAFTA concessions; yet they have been losing share in the US market to Asian products. Apparently something else is required, on top of the trade preferences.

Volatility of capital flows is indeed a matter for concern. In a situation where it has become clear that supervision at the financial centres are not as efficient as one would have thought and expected it to be, and even more, in a context where new players (such as sovereign funds) are having an increasingly important role, this poses a challenge to macroeconomic policies in developing economies. Nevertheless, it is not clear to what extent this means a case for regional integration. This seems to be more an argument for monetary coordination, eventually with the formation of common funds to provide liquidity in emergency situations. A quite different role than, say, constituting regional development financing agencies, a dimension more closely linked to fostering 'regional economic spaces'.

Next section discusses some initiatives that have taken place in Latin America with regard to development financing mechanisms and monetary and financial cooperation.

\section{Does a New Regional Integration Agenda Comprise Monetary Cooperation?}

\footnotetext{
${ }^{5}$ Such as trade creation, gains from scale, compensation for the adverse effects of rents created by selective restrictions in some sectors and others.
} 
Financial and monetary cooperation has been an issue in regional integration for quite some time. The opening of the capital account in the 1990s reinforced the need for some joint measures, as the power of small economies to deal with massive flows of international capital is very limited. Policy choices are limited to attaching the national monetary system to one of the strong currencies, to join forces in regional groupings by monetary and financial cooperation or pursuing active interventions in exchange markets and accumulating international reserves (UNCTAD 2007).

In Latin America the experience goes back to the 1960s, when Central American economies created a clearing house and in 1969 founded the Central American Monetary Stabilization Fund to finance payments imbalances. In 1965 LAFTA established a reciprocal credit and payment agreement among central banks. In 1978 the Andean countries created the Andean Reserve Fund (later transformed into the present FLAR Latin American Reserve Fund). Clearing mechanisms among Central Banks proved very helpful in the 1980s, as an instrument that allowed the revival of regional trade in a period of binding dollar shortage. Initiatives like the Andean FLAR are seen as successful examples of balance of payments financing through pooling of reserves: in over twenty years of operation it has played a role as important as the IMF in providing resources to the Andean countries as well as in supporting the smallest economies of the region (ECLAC 2002).

Latin America countries have less experience in establishing mechanisms for stabilizing exchange rates, such as the European Monetary System which developed into the European Monetary Union, the Eastern Caribbean Currency Union, and the Common Monetary Area in South Africa. As a matter of fact, variations in bilateral parities have strongly affected regional trade within some groups of countries, such as in MERCOSUR in the late $1990 \mathrm{~s}$.

One recent initiative with the multiple objectives of dealing with the mismatching of bilateral parities with regard to the dollar, at the same time reducing transaction costs and hence foster regional trade was adopted by Brazil and Argentina. In the January 2007 Presidential Summit of MERCOSUR the two countries agreed on the use of domestic currencies for bilateral trade. It is expected that some $20 \%$ of bilateral trade might be affected and that the reduction in transaction costs might reach $3 \%$. Small and medium enterprises are expected to benefit most from this measure. From the moment the proposal was made Uruguay and Paraguay decided to remain adopting the US dollar for their transactions, so that the initiative remains essentially a bilateral agreement between Argentina and Brazil, to start operating in 2008.

No integration scheme in Latin America meets at present the basic requirements to form a monetary area. CARICOM members aim at adopting a common currency by 2009 , but there is still some way to go in terms of adjustment measures in that direction. Yet reducing transaction costs might bring about significant results: Chagas andBaumann (2007) estimate that the adoption of a common currency in MERCOSUR would provide gains worth $0.9 \%$ of GDP only in terms of the reduction in those costs. The perspectives for a monetary union in MERCOSUR, however, are bleak.

Recent initiatives are more related to improving long-term financing. Development financing in Latin America has been predominantly provided by the World Bank, the InterAmerican Development Bank (IDB), by CAF-Andean Development Corporation, the Central American Economic Integration Bank (CABEI) and the Caribbean Development Bank (CDB), apart from some national development banks, such as the Brazilian National 
Economic and Social Development Bank (BNDES) among other institutions. This is not to say, however, that resources are available at the amount or the cost and term conditions required to financing the much needed infrastructure projects. There is still a long distance from an ideal situation and proposals have ranged from joining the available resources of existing institutions to creating new, regional banks.

The project of a Southern Bank (Banco do Sul) was initially proposed by Venezuela in January, 2007. Brazil reacted negatively to that proposal. The argument was that creating a new bureaucracy was something to be avoided. It was agreed that some mechanism is due to help foster financing of large projects in the region, therefore Brazil suggested more intense joint operations by its National Development Bank (BNDES), the Argentine Banco de la Nación and the Venezuelan Development Bank. Brazil even increased its participation in the Andean financing institution CAF with an additional US\$200 million, so as to improve project financing in South America. It turned out, however, that as early as in March 2007 Brazil changed its position and accepted Argentina's invitation to join the negotiations to form the Southern Bank.

The Southern Bank project sheds more doubts than lights. It is originally conceived as a development bank, to provide financing to large projects. But it is also often referred to as an alternative fund to the IMF (as different from the Asian experience, where the initiatives are designed as complementary to the multilateral institutions), with less strict criteria imposed on member countries to have access to its resources. It is not clear at the time of writing to what extent lending will take place on a concessional basis, and if so how the Bank is going to be funded. The formal launching of the Bank by the presidents of the participating countries took place in December 2007. It remains to design its operational characteristics.

A parallel initiative took place in January, 2008. On the VI Presidential Summit of ALBA the presidents of Venezuela, Bolivia, Nicaragua and the vice-president of Cuba announced the creation of a Bank for ALBA, with an initial capital of US\$ 1 billion. The bank shall provide credit to the member countries, and Venezuela has asked its partners to divert their international reserves from the US into the ALBA Bank.

Monetary cooperation and joint initiatives in financial matters in Latin America are less developed than in other regions. Compared to East Asia, where one sees efforts to develop a regional bond market (for instance, the Asian Bond Markets Initiative, launched in 2003 by ASEAN+3), surveillance mechanisms to detect financial market instability, the recycling of external surpluses into financing investment and other financial cooperation initiatives (like the Asian Bond Fund initiative by the Executive Meeting of the East AsiaPacific Central Banks group), Latin America still has a long way to go. It goes without saying that the low intra-regional trade also raises doubts about the probability of success in adopting a common currency, in most groups of countries. ${ }^{6}$ National monetary policies are defined on an individual basis by each country and there is nothing similar, for instance, to the East Asian proposal of a regional monetary fund, even though the Latin American Fund (FLAR) has been in operation for three decades now and is recognized as having contributed significantly in helping Andean countries meet foreign exchange shortages,

\footnotetext{
${ }^{6}$ Also, in the case of Mercosur, the lack of supra-national institutions: it is hard to see how, in an intergovernmental model of regional integration, can one deal with a common currency. The most successful example of regional integration in an inter-governmental model - the Nordic countries - has never gone that far.
} 
Initiatives have so far been concerned with the availability or resources to finance (mostly infrastructure) projects and - except for the specific experience of FLARonly recently have encompassed the pooling of reserves to deal with payment constraints.

In a changing international environment with globalised financial markets, it becomes increasingly clear that regional integration initiatives cannot focus exclusively on real economic problems, but that some kind of monetary and financial cooperation has to be part of the regional integration agenda. If the various integration schemes are serious about creating a single market, then they will also have to step up cooperation in the financial sphere. This need not imply that they will have to go as far as European countries and adopt a single currency, but completely ignoring issues of financial and currency stability is not an option either.

\section{Final Remarks}

It has been said with regard to Brazil's approximation with its Southern Cone neighbors that the relation with other countries is a matter of choice, but the intensification of links within the Southern cone is destiny, meaning that negotiating processes in this sub region are not demand-driven but are unavoidable.

This affirmative reflects to a large extent the very lack of consensus within the Brazilian society with regard to the importance of being part of regional integration schemes.

Brazil is, of course, an original member of both LAIA and MERCOSUR. However, the size and productive diversity of the Brazilian economy gives it a double role, as far as regional integration is concerned. It attracts potential partners aiming at improving their share of a larger market. At the same time, from the Brazilian perspective it is only some productive sectors that have clearly identified advantages in neighbouring countries, so that partner countries face strong resistance in achieving additional concessions as well as lack the capacity to jointly explore external markets.

This is hardly a natural path leading to regional leadership and reflects to a large extent the difficulties of identifying common interests among countries of markedly different economic sizes. The same logic - with perhaps less intensity - applies to most groups of Latin American and Caribbean countries. What is not clear, though, is how that destiny should be met: whether in terms of formal contracts - and if so, on what basis - or else in terms of simply reducing barriers to economic relationship of any kind and leaving market forces to operate freely.

The case for regional integration agreements has to do with the perception that there might be gains if the process of approximation is oriented by generic, agreed rules, and that differentiated concessions to neighboring countries are likely to generate specific benefits.

Geography matters, but is not a sufficient condition. Looking for such dynamism on an extra-regional basis brings about a number of questions and imposes the need for justifying the efforts required to consolidate regional integration. Stressing the importance of strong economic links with neighboring countries compels the participants to find common objectives and agree on the trajectories to reach them.

The list of potential reasons for putting efforts into building a regional agreement is long and varies according to the circumstances of each country. A tentative but by no 
means exhaustive list would comprise increasing market access; absorbing gains from scale; fostering the provision of regional public goods; improving competition in the domestic market, by reducing oligopolistic gains; improving negotiating capacity in international forums; complementing the domestic supply of basic inputs, such as energy and water; reducing bilateral exchange rate imbalances; improving the attractiveness for potential foreign investors and others.

Identifying the main objective or objectives is not an easy task, for it demands the convergence of the different perspectives in each society. Facilities in the access to external financing, the attractiveness of acquiring access to the main markets via extra-regional agreements and a weakened multilateral trade regulatory system only add more variables into this decision process. A less dynamic international market would attach further elements to be considered, to the extent that the regional market can be expected to partially compensate for this fall in external demand.

This article has argued that the arguments in favour of integration in Latin America were far more identifiable in past decades than they are today, be it for the increasingly important alternative of extra-regional preferences, or the need for a more ambitious negotiating agenda or even the probability that global variables influence the outcomes of intra-regional relations.

This is not to say that regional integration is not important. Theory and evidence suggest that it can be instrumental for economic and social development. Regional agreements might be an escape valve in a world with a weakening multilateral system; alternatively, if regional agreements are 'building' instead of 'stumbling' blocks they might be helpful in reinforcing the multilateral system. Regional integration can also be a means to provide dynamism and productive sophistication of national productive structure, at the same time that it might supply regional public goods, an important tool for development.

The point raised here is that on the basis of the recent Latin American experience the outcome is below the desirable level because, among other reasons, there is a lack of clarity in many countries with regard to what can be expected from regional integration, as different from alternative negotiations.

The present dilemma facing policy-makers in this region is that without a clear view about the purpose of regional integration the negotiating processes lack clarity and the outcomes are likely to be slow and unclear. Motivation from a shared understanding could help to identify the means to reach common goals. 


\section{REFERENCES}

Baumann, R. 2000. "A Integração Regional vista pela CEPAL" In Poletto, D.W. (org). 50 Anos do Manifesto da CEPAL. Porto Alegre: Edipucrs, pgs 115-120

Baumann, R. and A.M. Franco. 2002. Algumas Implicações do NAFTA para a Participação do Brasil na ALCA. IPEA/IPRI. Coleção Economia e Diplomacia, Brasília

CEPAL. 1979. Reexamen de la Integración Económica en América Latina y Búsqueda de Nuevas Orientaciones. E/CEPAL/R.209. Comisión Económica para América Latina y el Caribe: Santiago, Chile

CEPAL. 1985. "Las Relaciones Económicas Internacionales de América Latina y la Cooperación Regional". Estudios e Informes de la CEPAL, no. 49. Comisión Económica para América Latina y el Caribe: Santiago, Chile

Chagas, L. and R. Baumann. 2007. "Integração Monetária no Mercosul: Ganhos com Menores Custos de Transação?", Economia Aplicada, 11 (1): 95-112.

Comunidad Andina de Naciones. 2006. "Documentos elaborados por las Secretarías Generales de la Comunidad Andina, MERCOSUR y ALADI para el proceso de convergencia sudamericano", http://www.comunidadandina.org/csn/estudios.htm

Devlin, R. and P.Giordano. 2004. "The Old and New Regionalism: Benefits, Costs and Implications for the FTAA". In Estevadeordal, A., D. Rodrik, A.M.Taylor and A. Velasco (orgs), Integrating the Americas - FTAA and Beyond. Cambridge, Massachusetts: Harvard University Press

ECLAC. 1952. Economic Integration and Reciprocity in Central America. E/CN.12/AC.17/3. Economic Commission for Latin America and the Caribbean: Santiago, Chile

ECLAC. 1959. The Latin American Common Market. Economic Commission for Latin America and the Caribbean: Santiago, Chile

ECLAC. 1984. The International Economic Relations and Regional Co-Operation of Latin America. Economic Commission for Latin America and the Caribbean: Santiago, Chile

ECLAC. 1994. Open Regionalism in Latin America and the Caribbean. Economic Commission for Latin America and the Caribbean: Santiago, Chile

ECLAC. 2002. Globalization and Development. Economic Commission for Latin America and the Caribbean: Santiago, Chile.

ECLAC. 2006. Latin America and the Caribbean in the World Economy - 2005-2006.

Economic Commission for Latin America and the Caribbean: Santiago, Chile 
ECLAC. 2007. Latin America and the Caribbean in the World Economy - Trends 2007. Economic Commission for Latin America and the Caribbean: Santiago, Chile

UNCTAD. 2007. Trade and Development Report - 2007. United Nations Conference on Trade and Development: Geneva

Vaillant, M. 2007. "Convergencias y Divergencias en la Integración Sudamericana", CEPAL, Serie Comercio Internacional no 83. Comisión Económica para América Latina y el Caribe: Santiago, Chile

Veiga, P.M. and S.P.Rios. 2007. "O Regionalismo pós-liberal na América do Sul: Origens, Iniciativas e Dilemas", CEPAL, Serie Comercio Internacional no 82. Comisión Económica para América Latina y el Caribe: Santiago, Chile 